DOI: https://doi.org/10.34069/AI/2021.44.08.16

How to Cite:

Bandurko, Z., Blazhko, M., Liepukhova, N., Kovbasyuk, L., \& Kishchenko, Y. (2021). Translation of German anthroponyms in a novel "Die Abenteuer des Werner Holt" (Book 1) by Dieter Noll: linguistic and cultural aspect. Amazonia Investiga, 10(44),

168-177. https://doi.org/10.34069/AI/2021.44.08.16

\title{
Translation of German anthroponyms in a novel "Die Abenteuer des Werner Holt" (Book 1) by Dieter Noll: linguistic and cultural aspect
}

\section{Переклад німецьких антропонімів у романі Дітера Нолля „Die Abenteuer des Werner Holt““(Книга 1): лінгвокультурологічний аспект}

Received: July 10, 2021

\begin{abstract}
The article considers the translation of German anthroponyms in a literary text, taking into account the achievements of modern linguistic and cultural studies. The research is based on the theory of precedent and the following research methods: etymological, word-formation analysis, lexical-semantic analysis, analysis of dictionary definitions, linguistic and stylistic analyses etc. To achieve the purpose of scientific research, such an algorithm of actions is applied: 1) establishment of precedent phenomena and surnames, determination of the association to which they appeal; 2) analysis of the method of transferring German surnames in the Ukrainian translation; 3) identification of translation decisions. The study was based on 190 surnames of characters from Dieter Noll's novel "Die Abenteuer des Werner Holt" (Book 1). The system of surnames of the novel is divided into two groups: precedent and fictional. Precedent onyms denote famous writers, philosophers,
\end{abstract}

Accepted: August 30, 2021

Written by:
Zinaida Bandurko $^{61}$
https://orcid.org/0000-0003-0238-344X
Mariia Blazhko
ht
https://orcid.org/0000-0002-2183-7702
Nataliia Liepukhova ${ }^{63}$
http://orcid.org/0000-0001-7476-559X
Larysa Kovbasyuk $^{64}$
https://orcid.org/0000-0002-1441-2458
Yuliya Kishchenko ${ }^{65}$
https://orcid.org/0000-0002-0899-7322

\section{Анотація}

У статті розглядається переклад німецьких антропонімів у художньому тексті із урахуванням здобутків сучасної лінгвокультурології. Дослідження грунтується на теорії прецедентності та таких методах дослідження: етимологічному, словотвірного аналізу, лексико-семантичного аналізу, аналізу словникових дефініцій, лінгвостилістичного аналізу та ін. Для досягнення мети наукового пошуку застосований наступний алгоритм дій: 1) встановлення прецедентних феноменів та прізвищ, визначення асоціації, до яких вони апелюють; 2) аналіз способу передачі німецьких прізвищ в українському перекладі; 3) виявлення перекладацьких рішень. Матеріалом дослідження слугували 190 прізвищ персонажів роману Дітера Нолля „Die Abenteuer des Werner Holt“ (Книга 1). Систему прізвищ роману поділяємо на дві групи: прецедентні та фіктивні. Прецедентні

\footnotetext{
${ }^{61}$ Ph.D. in Philology, Senior Lecturer, Kherson State University, Faculty of Ukrainian and Foreign Philology and Journalism, Department of Germanic and Romanic Philology, Ukraine.

${ }^{62}$ Ph.D. in Philology, Associate Professor, Nizhyn Gogol State University, Faculty of Foreign Languages, Department of German Language, Ukraine.

${ }^{63}$ Ph.D. in Philology, Associate Professor, Nizhyn Gogol State University, Faculty of Foreign Languages, Department of German Language, Ukraine.

${ }^{64}$ Ph.D. in Philology, Associate Professor, Kherson State University, Faculty of Ukrainian and Foreign Philology and Journalism, Department of Germanic and Romanic Philology, Ukraine.

${ }^{65}$ Ph.D. in Pedagogy, Associate Professor, Kherson State University, Faculty of Ukrainian and Foreign Philology and Journalism, Department of English Philology and Applied Linguistics, Ukraine.
} 


\section{AMAZONDA}

generals and others. Fictitious onyms are divided into German surnames, foreign surnames and author's surnames. German surnames are of German origin. The second group singles out surnames of Slavic origin. Author's surnames are characterized by a certain connotation and influence on the reader. The reproduction of German surnames in the Ukrainian translation takes place by means of transcription and transliteration.

Key words: anthroponym, Dieter Noll, linguoculturology, translation, surname.

\section{Introduction}

The complex theoretical and practical issues that need to be solved in modern philological and translation studies include onyms of the literary text. Proper names are an important component of any national culture. Traditionally, onyms have been the subject of onomastics, which distinguishes proper names from living beings and inanimate objects. Myaskovskaya T.V. \& Semina V.V. (2014) have proposed the following classification: personal name, patronymic name, surname, nickname, pseudonym, cryptonym, anthroponyms formed from ethnicons.

Modern interest in anthroponyms is explained both by the anthropocentric approach to the study of linguistic phenomena and by the interdisciplinarity of anthroponymy. Anthroponyms are the element that connects a person with their immediate environment and society as a whole. Names create a certain continuum around a person, a specific national and cultural space, common to the whole language community and individual for each of its members (Rylov, 2006: 5). Linguists emphasize the important role of anthroponyms in the system of proper names of a literary text, which is explained by the anthropocentric nature of literary works, stylistic and functional potential of this category of words (Bobro \& Prysiashniuk, 2021: 57).

In our scientific research, we adhere to the understanding of the text as a fragment of the conceptual picture of the world and a phenomenon of culture (Kubriakova, 2004). The cognitive approach emphasizes the complex nature of texts that are objectified through language and special language forms. Such texts are considered to be both the result of the mental activity of individuals living in a certain place and specific socio-historical conditions, whose оніми позначають відомих письменників, філософів, полководців та ін. Фіктивні оніми поділяються на німецькі прізвища, іншомовні прізвища та авторські прізвища. Німецькі прізвища мають власне німецьке походження. У другій групі виокремлюються прізвища слов'янського походження. Авторським прізвищам властива певна конотація та вплив на читача. Відтворення німецьких прізвищ в українському перекладі відбувається шляхом транскрипції та транслітерації.

Ключові слова: анторопонім, Дітер Нолль, лінгвокультурологія, переклад, прізвище.

speech reflects the relevant socio-cultural and psychological factors (Kubriakova, 2004: 516).

This suggests that texts are the result of discursive, i.e. socially-oriented and socially conditioned communicative activity. The text is thus widely considered as an open structural complex that encourages the researcher to take into account in their linguistic researches the conditions of text generation, factors influencing its understanding, as well as factors of the addressee and the sender (Heinemann \& Heinemann, 2002; Semochko, 2012: 204). Understanding the text as a result of speechthinking and discursive human activity allows us to assume that linguistic devices fix values, ideals, as well as socio-ethical and cultural priorities of society and the individual. So, any text reveals national-cultural specificity and ability to convey the individual characteristics of communication participants, and therefore can be considered as a fragment of the conceptual and linguistic picture of the world (Kuße, 2012: 38; Mizin \& Letiucha, 2019).

The above written explains the growing interest of researchers in precedent phenomena. Linguist Yu. Karaulov (1987), the developer of the concept of linguistic personality, was the first to substantiate the scientific basis for the introduction of the term precedent text. To be considered as precedent, the text must meet three criteria: be meaningful to a particular individual in cognitive and emotional aspects; be noted for its superpersonal character, i.e. be widely known to representatives of different generations within one linguistic culture; be repeatedly reproduced by each individual in their discourse (Karaulov, 1987: 216). V. Krasnykh (1997) proposed to distinguish precedent texts and precedent phenomena, by which the researcher understands 
verbal and verbalized units. The precedent name and precedent statement belong to the first group, and the precedent text and situation to the second.

Precedent texts and precedent phenomena preserve social and cultural information. They often have a concise form, extreme expressiveness and capacity, show the ability to unfold the entire content of the text in the mind of the individual, provided that both communicators belong to the same linguistic culture. Therefore, their language form can take the form of one token - its own name, onym. The most important is the set of information that does not undergo significant changes in any interpretation. This property of precedent phenomena makes them easy to recognize and understandable for representatives of different generations of the same linguistic culture (Semochko, 2012: 205).

Under this approach, fiction acquires special significance as a reflection of a syncretic image of national character, in the genres of which precedent texts are widely used as carriers of culturally significant and conditioned information. In the process of translating such texts, the translator must make decisions related to both the recognition of precedent phenomena in the original text and the peculiarities of the transmission of culturally specific information by means of another language.

\section{Literature Review}

Everyone who begins to study a foreign language cannot comprehend various facts and realities of life in another country until they have learnt enough information about the mentality, way of life, prejudices of the people whose language is being studied. National languages differ not so much in individual parameters as in the whole set of verbal and nonverbal information (Grishaeva, 2008: 118). The source of such nonverbal information in an artistic text is units of different language levels, among which anthroponyms play an important role.

The surname, a constant component of an anthroponym, is the element that is inherited. The surname is traditionally considered as an important part of people's history, of their language: knowledge of the etymology of surnames gives an idea of the origin of ancestors, their occupation, hallmarks of man. Surnames contain information about the social status and place of residence of the individual.

Anthroponyms as special linguistic units are the object of study of modern linguists, taking into account different perspectives of scientific research. Very perspective in modern linguistics is the analysis of onomastic strategies used for self- and other-referencing as part of mobile phone interaction (Aldrin, 2019). Thus, the investigation of the influence of social factors on the name giving from the linguistic point of view can be considered significant (Zerkina et al., 2018) and a research work of proper names from a corpus linguistic point of view, which presents their linguistic status, meaning and grammar and seeks to outline the theoretical foundations for establishing a connection between onomastics and corpus linguistics can be considered important (Motschenbacher, 2020).

In addition, anthroponyms can have a manipulative effect on human consciousness. Manipulation is understood, following Dutch linguist T. van Dijk, as a form of domination or abuse of power associated with control of consciousness, access to knowledge and information, and the influence on mental models, emotions, any ideas and beliefs (Dijk, 2012; Maillat, 2013). It is believed that in any communication you can use any language resources to manipulatively influence the cognitive and behavioral activities of the recipient, which allows you to change the knowledge of the recipient, to predict their emotional reactions and behaviour (Peshkova, 2017).

It has been established that an important method of implementing manipulative influence in media discourse is the appeal to emotionally charged precedent phenomena (Sakharuk, 2015). The functions of precedent units in modern German and Ukrainian religious media discourse have been considered and their manipulative influence on the addressee of communication have been clarified (Levko, 2021: 126).

The manipulative influence of proper names in the period of National Socialism, including anthroponyms, on the consciousness of the Germans has already attracted the attention of philologists. In particular, it was proved that the German names of that time should have emphasized the "blood and spiritual" kinship with the ancient Germans, people and gods of the North. Popular at that time, on the one hand, were the ancient Germanic names Dieter, Detlev, Margit, Ingrid, Uta, and on the other - double names due to their sound and rhetorical nature. Double names were written through a hyphen, for example: Berndt-Walter, Dietmar-Gerhard etc. (Klemperer, 1998: 42-43). 


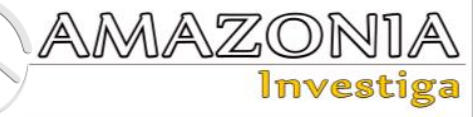

One of the most problematic elements for translators of literary works is proper names. A translator of a literature work deals with very important questions: Should proper names be translated or not? What are the main problems on the way of their translation? (Meyer, 2008; Nyangeri \& Wangari, 2019). In addition, translators pay attention to the theoretical development of the translation of proper names: researchers have identified a set of translation techniques that are recommended for use in the reproduction of proper names - transliteration, transcription, transposition and tracing (Zacharova, 2019: 243). On the other hand, the ability of purely mechanical selection of appropriate phonemes or graphemes in the target language is not enough. The translation of proper names as well as surnames requires from the translator taking into account a number of different factors: the specifics of the language environment of the name, its complex semantic structure, unique features of form and etymology, word-forming characteristics, connections with other categories and units of the language. Ignoring these properties of the name creates a number of practical problems that the translator needs to deal with in practice (Nuriev, 2013: 11-12). Besides, it is important not only to identify specific translation problems, but also the phenomenon of decision-making by the translator under conditions of multiple choice (Dorofeieva \& Kotsur, 2020: 92).

The lack of sufficient research on the linguistic and cultural specifics of German surnames of the National Socialist era, taking into account the modern theory of precedent, determines the relevance of the study.

Therefore, the purpose of our research is to determine the linguistic and cultural aspects of the characters' names in the novel "Die Abenteuer des Werner Holt" by Dieter Noll (Book 1) (Noll, 1984), to analyze the methods of their translation and the peculiarities of the translator's decision-making. It should be emphasized that the study of various ways of translating surnames into Ukrainian is a responsible task for every translator, for if the features of the historical epoch, culture and social order are misunderstood it can lead to inadequate translation.

\section{Methodology and Material}

General scientific (observation, generalization, description) and special research methods were used in this work. The etymological method was used to determine the origin and development of the meanings of surnames. The ways of creating German and Ukrainian surnames were revealed by the method of word-formation analysis. The method of analysis of dictionary definitions was used to establish and clarify the content of the surname; the method of lexical and semantic analyses was used to determine the semantics of surnames and reveal their additional meanings. Phonetic, lexical, semantic and stylistic properties of the studied units were established by the method of linguistic and stylistic analyses. The descriptive method was used to determine the translation strategies of transliteration and transcription of German surnames of Dieter Noll's novel in the Ukrainian translation by Yuriy Mykhailyuk.

To achieve this purpose we offer an algorithm of actions, which consists of three stages. At the first stage of our research it is necessary to identify precedent phenomena and surnames of the characters of the novel and to determine the associations to which the surnames appeal and which are realized in the text of the novel. At the second stage, we establish the most common way of rendering German surnames in the Ukrainian translation of the novel. At the third stage we analyze successful and unsuccessful decisions of the translator.

The study was based on 190 surnames selected by a continuous sample from the text of the novel "Die Abenteuer des Werner Holt" by Dieter Noll, and their Ukrainian equivalents (Noll, 1984; 1961).

\section{Results and Discussion}

Addressing the manifestation, reflection and fixation of culture by German surnames in the text of the novel "Die Abenteuer des Werner Holt" by German writer Dieter Noll and their Ukrainian translation is both an urgent and a difficult task. The artistic world of this work is distinguished by its linguistic and cultural specifics, as it reveals a connection with the world's and German history. The novel depicts the events of 1933-1945, the most tragic period of time in both social-political and cultural life of Germany.

The text of the first book of Dieter Noll's novel was published in 1960 and the Ukrainian translation appeared five years later. The time of the creation and publication of the novel was turbulent: the final partition of Germany was in its progress, the construction of the Berlin Wall was completed. The global Caribbean crisis had put the world at risk of a nuclear catastrophe, and 
the German leadership had been trying to acquire its own nuclear weapons in recent years (Heffernen, 2011). However, the then and present relevance of this novel, interest in its Ukrainian translation is explained not only by the anti-war nature of the work, but also by the skill of the author, who accurately portrayed reality, perfectly recreated the atmosphere of the historical period of World War II, depicted the spiritual world of his characters.

The artistic world, in which the protagonist of the novel, young romantic Werner Holt / Вернер Гольт and his peers exist, has a distinct linguistic and cultural specificity, embodied in the system of surnames of the novel, which are divided into precedent and fictitious.

By precedent surnames we mean the names of world-famous German and foreign writers, authors of musical works, military leaders, military theorists, philosophers $(22 \%$ of the total number of studied surnames). Precedent names preserve historical and cultural information about the world and society, reflecting the peculiarities of the development of human thinking. There is no coincidence that the author of the novel uses precedent names, as their involvement in the literary text helps to successfully characterize the individual, first of all, their mental state, ideological preferences, views.

The surnames of this group are used to reflect the gradual alienation of the new generation from the humanistic ideals, from the moral values embodied in the works of German or world literature and art. The author uses the names of the classics of German literature Rilke, Goethe, Schiller, Fontanne, Storm, foreign authors Dostoevsky, Jack London, Hugo, composers Rubinstein, Chopin, Haydn, Schumann, etc. to demonstrate the level of education of the main characters.

For example, a high level of intelligence, positive moral qualities, the presence of abstract, critical thinking, a high level of empathy of the novel's characters are embodied by appealing to the precedent names of the world literature classics, which are well known to a wide range of readers and evoke positive emotions. On the contrary, ignorance of the character, lack of knowledge of precedent names or texts are used for irony and cause a negative attitude of the reader to ignorance. For instance, Wolzow/Вольцов, one of the main characters, when asked if he reads Faust, explains the existence of this book in his library as follows: "Ich hab gehört, da soll ein Soldat mitspielen, ich hab mir das angesehn: militärisch ist es uninteressant" / "Я nросто чув, шчо там серед діючих осіб є солдат. Проглянув ті місия, - $з$ точки зору військового зовсім не иікаво” (Noll, 1984: 34; 1961).

The ideological preferences of the novel's characters, the militarization of society, the formation in the minds of young people of the cult of war are embodied through an appeal to the names of Roman, Germanic, German commanders, military theorists, historians: Marius, Verdy du Vernois, Rüstow, Prince Kraft zu Hohenlohe, Carl Gottlieb von Clausewitz etc. (Noll, 1984).

Romanticizing, glorification of war is the content of the literature by new German writers who gained recognition and popularity during National Socialism: the president of the Reichsschrifttumskammer Hanns Johst / Ганс Йocm, lyricist and playwright Walter Flex / Вальтер Флекс, poet Wulf Sörensen / Вульф Серенсен, writer Karl Мау / Карл Май; film director, author of the drama about Frederick the Great (1942) Veit Harlan / Вейm Гарлан etc. (Noll, 1984; 1961). These anthroponyms not only reflect information about the literary, musical, political, ideological preferences of the characters of the novel, but also mark the connection with the history and culture of Germany, as well as national and temporal specifics.

The group of fictitious surnames $(78 \%)$, i.e. the names of persons who exist only in the artistic world of the novel, is divided into three subgroups:

1. German surnames (58,6\%): Holt, Vetter, Küchler, Meißner, Kiefer, Weber, Klein, Kirsch, Schulze, Berger, Thieß etc.

2. Foreign surnames (6,4\%): Gomulka, Wolzow, Zemtzki, Kutschera, Revetcki.

3. Author's surnames (13\%): Gottesknecht, Ziesche, Knack, Schöner, Klage, Rutscher etc.

The surnames of the first subgroup can be interpreted by the German ground. For example, the last name of the main character of the novel Holt/Гольт contains the component -hol, present in such German words as Holz, hold etc. The noun Holz means forest, wood. According to the digital dictionary of German surnames "Digitales Familiennamenwörterbuch Deutschlands (DFD)", the name Holt was given to forest dwellers (DFD, 2021). The adjective hold is stylistically marked and contains an additional 


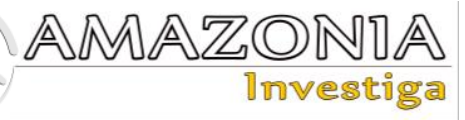

stylistic connotation "poetic, out-of-date". Thus, the bearer of the surname with such a component of meaning is characterized by such features as graceful, cute and noble. Thus, the surname Holt contains stylistic and extralinguistic information, so it can be considered eloquent. We assume that the surname Holt is an allusion to the surname of the author of the novel Noll, which also consists of four letters and contains the component $-o l$.

Wiese/Bize is a classmate and friend of Holt. The name of the person comes from the Old German noun wisa "meadow", therefore, its first bearer lived on or near an open lawn. The name Wiese was first mentioned in the Middle Ages. This family name originated in Silesia and belonged to the most influential families in the region (DFD, 2021). Both surnames, Holt and Wiese, are short, simple in structure, so we can assume that these two characters are descendants of ancient German families. The correlation of the bearers of these surnames, who are positive characters of the novel, forms a positive attitude towards the objects of the author's sympathies.

This assumption is confirmed by the etymological analysis of the surname of one of the few female characters - Thieß/Tic: the German surname Thie $\beta$ is formed from the nickname Thieß. According to another version, this surname is derived from the patronymic Matthias, which was formed by omitting the unstressed syllable of the name Mat- (DFD, 2021). The character of Gundel Thieß / Гундула Tic, a small girl in red boots, unlike other girls, who is forced to perform chores in the large family of a German officer, is an allusion to the image of the girl from Theodor Storm's novella "Immensee".

The surname Bурм/Wurm, which means "worm" in German, is also simple and short and evokes the associations of a small, insidious person who inspires fear and looks like a worm (DFD, 2021). This name is an allusion to the villain Wurm in Schiller's tragedy "Intrigue and Love" / "Kabale und Liebe". In the play, he is the "Secretary of the President", an inner barbarian responsible for all the insidious conspiracies against love.

The German surname Hampel/Гампель may belong to Lower Sorbian names, meaning "greedy man" (DFD, 2021).

Other German surnames in this subgroup, such as Küchler, Meißner, Kiefer, Weber etc., reflect the social status of the speakers. Some of them are formed by adding the suffixes $-e$, $-e l$, $-e r$ to the creative basis of the corresponding verb to denote professional activity: weaver (Weber), lumberjack or cloth merchant from the town of Meißen (Meißner), gardener or cherry merchant (Küchler), cooper (Kiefer). The surname Schulze/Шульие is derived from the name of the profession of an authorized person who represents the interests of a certain group of persons or a territorial district before the court (DFD, 2021).

The suffix -er is used to form the surname Berger/Бергер from the noun Berg "mountain", which indicates the place of residence or the origin of its bearer (DFD, 2021).

The name of the main character's classmate Vetter/Фemmep evokes associations with the adjective fett "fat", which corresponds to the author's characteristics of this character. The author draws attention to the boy's overweight, his round child's face, his shiny pig's eyes, his flabby and slightly swollen body, because of which he was always mocked at (Noll, 1984: 150). However, modern etymological dictionaries allow another understanding of this surname: cousin (DFD, 2021).

The criterion for distinguishing foreign surnames of the second subgroup is the common Slavic origin of their bearers: Gomulka, Wolzow, Zemtzki, Kutschera, Revetcki. It is known that a large part of Germany was inhabited by the Slavs at different times, which is reflected primarily in geographical names. Until the mid-1930s, a large number of toponyms of Slavic origin were preserved in Germany. In the names of settlements in the north and east of Germany there was an adjective wendisch, i.e. "Wends" (Lusatian Serbs) - a Slavic ethnic group that still lives in Germany. During National Socialism, the names of many towns and villages were changed. For example, the adjective wendisch was removed from the compound names of some settlements in the historical principalities of Pomerania, Brandenburg, the regions of the Spreewald and Silesia (Datsishina, 2020: 114; Klemperer, 1998: 46-67).

The surname Kutschera/ Kymuepa is a German variant of the Slavic surname Kucera or Kuczera. The Kucera variant is of Czech or Slovak origin and means "curls". This is the name of a person with curly hair. The spelling of the surname Kuczera contains the sibilant sound $-c z$, that is not peculiar to the German phonetic system, which suggests the Polish origin of the name. The bearers of this surname were curlers (DFD, 2021). Using the method of observing the functioning of the surname Kutschera in the text 
of the novel, it is established that the author uses this anthroponym without a name, usually with the appellative Hauptmann/капітан (captain). Obviously, the purpose of such use is to program the emotional response of the reader's alertness, which monitors the unfolding of the events of the novel.

The surnames Wolzow/ Вольциов and Gomulkal Гомулка are of Slavic origin. The former contains the element $-o w /-o b$, which allows us to make assumptions about Wolzow's ancestors, who may have originated from the area where the Lusatian Serbs used to live. Lusatian roots have toponyms ending in -au or -ow (-owe, -ouwe). In the novel, Wolzow is the personification of a man who is passionately devoted to military service, blindly believes in the victory of Germany and remains loyal to the regime. If we take into account the origin of the character named Gomulka, whose family lived in Dresden, his ancestors could have lived in Poland.

Slavic origins can also be traced in two other surnames: Zemtzki/Цемцький and Revetcki/Ревеиький, which have an obscure etymology and end in -tzki/-tcki.

The surnames of the third subgroup are author's formations: Gottesknecht, Ziesche, Knack, Schöner, Rutscher. Thus, the surname of caretaker Gottesknecht/Готтескнехm consists of two components: the noun Knecht "servant" and the attribute expressed by the noun in the genitive case, Gottes "God". The semantic transparency of this eloquent surname, its positive emotional connotation have stylistic potential and manipulative influence on the mind of the reader. The sense of humor, self-irony of a former teacher of German literature and a class teacher of young cadets are embodied through an appeal to the name, which is undergoing transformation. The author expands the name due to the word Teufel "devil", which has a negative emotional impact. Gottesknecht presents himself to young soldiers as follows: „Die mich kennen, $<\ldots>$ die sagen, ich sei wirklich Gottes Knecht, aber wer hier groß angibt, der wird meinen, ich sei des Teufels. "/ «Ti, хто знає мене, говорять, начебто я справді «слуга божий», а хто заважатиме на уроках, той швидко переконається, що я слуга самого чорта» (Noll, 1984; 1961). The creation of the pun Gottesknecht - Knecht des Teufels enriches the expressiveness of the text, attracts the reader's attention and makes them think about the tragedy of the situation, the circumstances of which force the former literature teacher to become a caretaker.
The anthroponym Ziesche also has a hidden meaning. The author describes the appearance of this character as follows: "war ein gedrungener blonder Junge von siebzehn Jahren, etwas dicklich, mit weibischen Zügen, unreiner Gesichtshaut und einer großen Warze an der linken Schläfe." / “кремезний білявий юнак років сімнадияти, трохи товстуватий, 3 прищавим жіночим обличчям $i$ величезною бородавкою на лівій скроні." (Noll, 1984: 150; 1961). Obviously, a character with such characteristics of appearance should not cause sympathy. This name has phonosemantic associations with the sounds produced by the snake. Characterizing the features of the character's speech, the author chooses the verb zischen/uunimu "hiss" to create the image of an insidious person with an unpleasant appearance and speech defects and uses the technique of language punning: "Aber Ziesche zischte Holt ins Gesicht” / "Але Ціше прошипів йому прямо в обличчя" (Noll, 1984: 278; 1961).

Let's go on to the stage of rendering German surnames in the Ukrainian translation of the novel. Transliteration is considered to be the traditional way of translating names and surnames. The names of the first subgroup were rendered by transliteration: Ноlt/Гольт, Gomulka/Гомулка, Vetter/Феттер, Thieß/Tic, Wiese/Bize, Wurm/Вурм etc. Usually there is a combination and selection of options at the level of phonemes: the sounds of the original language are replaced by the sounds of the target text, closest to them in acoustic properties (Barchudarov, 1975: 176-177). Thus, in order to translate the German name Paul into Ukrainian, it is necessary to transliterate each German phoneme that is similar in articulation and sound to the phoneme of the Ukrainian language: [p] is replaced by the Ukrainian phoneme [ח], the diphthong [au] - by the corresponding vowels [ay], and the German phoneme [1] - by the Ukrainian consonant [л'].

It is believed that the translator makes decisions not only at the level of phonemes or graphemes, but also at the level of the whole text. The names and surnames of the characters become the keywords that help to adjust the formation of the meaning of the new text. The translator allegedly imposes cultural filters on the translation: they must take into account culturally conditioned associative connections, unwanted intertextual potential of the name, phonosemantic associations etc. (Nuriev, 2013: 57).

The translator reproduces most of the surnames in the Ukrainian translation of the novel by 


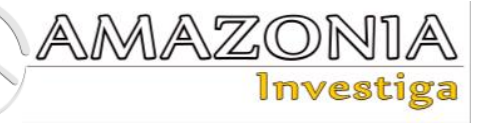

transliteration: the phonemes $-\ddot{o},-\ddot{o} h,-o e,-\ddot{u}$ are replaced by their Ukrainian equivalents $-e,-y$ or -ю, for example: Воеk/Бек, Schönеr/Шенер, Вӧhm/Бем, Düsenböker/Дузенбекер, Günsche/ Гюнше. Diphthongs -oi, -ei in German surnames are reproduced in Ukrainian by vowels -oŭ and eŭ, for example: Voigt/Фойгm, Klein/Клейн (Noll, 1984; 1961).

A number of surnames evoke various associations, which allows us to consider them eloquent. Those who do not know German, without special comments and explanations will not understand what the meaning of the name Wurm/Bypм is and why it is considered ugly. The world literature traditionally gives its characters "speaking" names that cannot be translated literally without changes, it would be considered as an anachronism. But it is also unfair to deprive the reader of translated works of those things in which the reader of the original finds new associations and colors (Galperina, 2018).

Let us consider the specific features of translating surnames of the second and third subgroups. In some cases, the translator makes decisions not so much at the level of phonemes or graphemes as at the level of the text as a whole. Rendering the German surname of Slavic origin Kutschera into Ukrainian, the translator offers a variant Кутшера: he transliterates the surname, without replacing the German letters -tsch with the Ukrainian $-\iota$, but chooses the letters - ти. The variant Kymmepa only remotely resembles the Ukrainian surname Kучера with the stress on the second syllable. Perhaps the translator deliberately avoids unwanted phonosemantic associations due to minor manipulations with the word form. The translator also makes some substitutions when reproducing the Ukrainian version of the German surname Rutscher as Рутиер.

The original translator's decision is observed when translating the surname of Dr. Zickel/Ціккель. The component of the surname Zick-denotes the sounds characteristic of a goat. At the first mention of this name, the translator chooses the variant ЦіккельMeмe/Zikkel-Meme, i.e. adds the nickname Meмe, which indicates the peculiarities of speech of this character: he stretches the words and inserts between them the sounds "me" or "mm". To convey this feature, the translator transliterates the last name: he renders the letter combination $-c k$ by the doubled $-\kappa \kappa$, and extends the last name by adding the Meмe component. In this way, the translator managed to convey to the
Ukrainian reader the phonosemantic associations of this surname.

When transmitting the eloquent surname Ziesche as Цime, the translator combines the techniques of transcription and transliteration: he correlates the phoneme $Z$ with the closest sounding phoneme of the Ukrainian language $Ц$; changes the phoneme -ie into $-i$ and the phoneme $-s c h-$ into the similar Ukrainian variant $-m$. However, this Ukrainian version in no way conveys the full range of negative associations that this name contains in the original text.

Associations containing the German surname Klage are also lost. The word Klage means "cry, groan" or "complaint": the bearer of this name appeals to the ethical norms of compassion, pity for the sick, old teacher; he tries to complain in order to protect himself from bullying and revenge of his students but receives no support. Thus, the Ukrainian reader will not understand the hidden meanings of this name. The Ukrainian version of the character's surname Dr. Klage contains some substitutions - the German phoneme $-a$ for the Ukrainian $-я$, which can be explained by the translator's desire to convey the pronunciation of the sound $-l$, which differs from the Ukrainian equivalent in softening.

\section{Conclusions}

Analysis of the German anthroponyms of the novel "Die Abenteuer des Werner Holt" by Dieter Noll in terms of precedent allows us to draw some conclusions on the linguistic and cultural specificities of surnames.

All the surnames of the novel form a system and are divided into precedent and fictitious surnames. Most of the analyzed surnames (78\%) are fictitious and differ in etymology, wordformation, semantic and stylistic potential. Precedent surnames (22\%) appeal to the positive or negative emotions of the reader in order to form sympathy or antipathy towards the actions of the characters of the novel, encourage the reader to empathize, vigilance.

Translation of German precedent and fictitious surnames in a literary text is not a purely mechanical selection of the corresponding letter combinations or phonemes in the target language. This task requires from the translator a full comprehension of the text principles by the reader and a differentiated approach to each case, taking into account a number of different factors. One of such factors may be the precedent nature of the name, which becomes a powerful means of 
creating an artistic image that performs various functions.

The prospect of further research is the study of the linguistic and cultural specificities and peculiarities of the translation of German anthroponyms in the second book of the novel. An interesting area of future research can be the creative work of Ukrainian translators of Dieter Noll's novels, Yuri Mykhailyuk and Yakov Prilipko, which will complement the picture of the history of Ukrainian-German literary translation of the second half of the 20th century. The in-depth study of the phenomenon of decision-making in translation from the standpoint of psycholinguistics is also promising.

\section{Bibliographic references}

Aldrin, E. (2019). Naming, Identity, and Social Positioning in Teenagers' Everyday Mobile Phone Interaction. Names, 67(1), 3039, https://doi.org/10.1080/00277738.2017.1 415523.

Barchudarov, L. S. (1975). Language and Translation (questions of general and private theory of translation). Moscow: International relationships.

Bobro, M. P. \& Prysiashniuk, L. R. (2021). Linguocultural semantics of anthroponyms and toponyms in J. Martin's novel "Game of Thrones" and features of their translation into Ukrainian. Bulletin of V.N. Karazin Kharkiv National University. Series "Philology", 88, 67-73.

Datsishina, M. V. (2020). Place renaming and German policy-making in temporarily occupied Soviet territories. Questions of onomastics, 17(1), 113-135. Recovered from http://dx.doi.org/10.15826/vopr_onom.2020. 17.1.006

Dijk, van T. A. (2012). Knowledge, discourse and domination. In M. Meeuwis \& J.-O. Östman (Eds.), Pragmaticizing Understanding: Studies for Jef Verschueren (pp. 151-196). Amsterdam, Philadelphia: John Benjamins Publishing Company.

Dorofeieva, M. \& Kotsur, A. (2020). Psycholinguistic Fundamentals of Nonlinearity in Translation. Psycholinguistics, 27 (2), 90-112. Recovered from https://doi.org/10.31470/2309-1797-202027-2-90-112

Galperina, E. I. (2017). The word alive and dead. Moscow: AST. Recovered from https://mybook.ru/author/nora-gal/slovozhivoe-i-mertvoe-3/read/
Germany Digital Surname Dictionary (DFD) (2021) The digital dictionary of surnames in Germany (DFD). Recovered from https://www.namenforschung.net/dfd/projekt vorstellung/.

Grishaeva, L. I. (2008). Precedent text as universal tool to transfer and storage of cultural information. Political linguistics, 24(1), 118-123. (in Russian)

Heffernen, M. (2011). The Significance of Europe. Geography and geopolitics. Kyiv: Dukh ISBN 0-340-66189-5; ISBN 978-966378-198-3 and the letter. ISBN 0-340-661895; ISBN 978-966-378-198-3

Heinemann, M. \& Heinemann, W. (2002). Grundlagen der Textlinguistik: Interaktion Text. Diskurs. Tübingen: Niemeyer.

Karaulov, Yu. N. (1987). Russian Language and Linguistic Personality. Moscow: Nauka.

Klemperer, V. (1998) LTI. The Language of the German Reich. A notebook of philologist. Moscow: Progress-Traditions.

Krasnykh, V. V. (1997). The system of precedent phenomena in the context of contemporary studies. In V.V. Krasnykh \& A.I. Izotov (Eds.), Language, Mind, Communication (Vol. 2, p. 5-12). Moscow: Filologija.

Kubriakova, E. S. (2004). Language and knowledge: on the way to gain knowledge about language: Parts of speech from a cognitive point of view. The role of language in the knowledge of the world. Moscow: Languages of Slavic culture. (in Russian)

Kuße, H. (2012). Cultural linguistics. An introduction. Göttingen: Vandenhoeck \& Ruprecht.

Levko, O. (2021). Precedent Units as a Means of Manipulation in Ukrainian Religious Media Discourse: Psycholinguistic Approach. Psycholinguistics, 28 (2), 99-127. Recovered from https://doi.org/10.31470/2309-17972020-28-2-99-127.

Maillat, D. (2013). Constraining context selection: On the pragmatic inevitability of manipulation. Journal of Pragmatics, 59 (B), 190-199. Recovered from https://doi.org/10.1016/j.pragma.2013.07.00 9

Meyer, B. (2008). Interprating proper names: Different interventions in simultaneous and consecutive interpreting. Trans-komm 1(1), 105-122.

Mizin, K. \& Letiucha, L. (2019.) The linguocultural concept Torschlusspanik as the representative of ethno-specific psychoemotional state of Germans. Psycholinguistics, 25 (2), 234-249. Recovered

from 


\section{AMAZONDA \\ ]ทvestigga}

https://doi.org/10.31470/2309-1797-2019-

25-2-234-249.

Motschenbacher, H. (2020). Corpus Linguistic Onomastics: A Plea for a Corpus-Based Investigation of Names. Names, 68(2), 88-103. Recovered from https://doi.org/10.1080/00277738.2020.1731 240

Myaskovskaya, T.V. \& Semina, V. V. (2014). Features classification of historical anthroponyms. Science and World, 2/12(16), $52-55$.

Noll, D. (1961). Adventures of Werner Holt. (Transl. by Yu. Mykhailyuk). Kyiv: Dnipro. Retrieved from https://libcat.ru/knigi/proza/prosemilitary/176842-67-d-ter-noll-prigodivernera-golta.html\#text [Accessed July 14, 2021]. (in Ukrainian)

Noll, D. (1984). Die Abenteuer des Werner Holt. Berlin, Weimar: Aufbau-Verlag (Original work published 1960).

Nuriev, V. A. (2013). Difficulties in translating proper names in a literary text. Moscow University Bulletin. Series 22: Theory of Translation, 2, 56-64.

Nyangeri, N.A. \& Wangari, R. (2019). Proper Names in Translation: Should They be Translated or Not? Eastern African Literary and Cultural Studies, 5 (3-4), 347-365. Recovered from https://doi.org/10.1080/23277408.2019.1680 914

Peshkova, N. P. (2017). Linguistic landscape of a poly-ethnic city: Specific features of verbal impact. Journal of Psycholinguistics, 33(3), 108-121.

Rylov, Yu. A. (2006). Proper nouns in European languages. Romanesque and Russian anthroponymics. Lectures in cross-culture communication. Moscow: AST: Vostok Zapad.

Sakharuk, I. V. (2015). Status of precedent units in the system of intertextual means of contemporary Ukrainian media discourse. Linguistic Magazine, $66 \quad$ (2), 127143. Recovered from https://doi.org/10.1515/jazcas-2016-0003

Semochko, S. V. (2012). Peculiarities of intercultural adaptation of precedent phenomen «Little man» from the N. V. Gogol-story «The Overcoat» with the arsenal of German language. Language, Communication and Social Environment, 10, 203-221.

Zacharova, D. \& Tomashevskaya, I. (2019). The problem of translating proper names in fantastic discourse (based on the animated series Adventure Time). Foreign languages: linguistic and methodological aspects, 43, 240-245.

Zerkina, N., Kisel, O., Savinova, Y., Zalavina, T., Kozhushkova, N. \& Akhmetzyanova, T. (2018). Name Giving Process: Linguistic and Extralinguistic Challenges. Glottotheory, 9(2), 131-146. Recovered from https://doi.org/10.1515/glot2018-0012 